\title{
Educating Values of Traditional Culture in Ho Chi Minh Heritage Treasure in Vietnam Today
}

\author{
Bui Van Tuyen \\ Vietnam Youth Academy, Ho Chi Minh City, Vietnam \\ Email address: \\ buivantuyenpvmn20@gmail.com \\ To cite this article: \\ Bui Van Tuyen. Educating Values of Traditional Culture in Ho Chi Minh Heritage Treasure in Vietnam Today. Advances in Sciences and \\ Humanities. Vol. 7, No. 2, 2021, pp. 44-48. doi: 10.11648/j.ash.20210702.16
}

Received: June 13, 2021; Accepted: June 26, 2021; Published: June 30, 2021

\begin{abstract}
The aim of this study was to clarify the education of traditional cultural values in the Ho Chi Minh heritage treasure in Vietnam today, with two hypotheses: 1/ educating traditional cultural values of the people in the treasure of Ho Chi Minh's heritage both in terms of theory and ongoing practice; 2/ The actual implementation of the contents of education on traditional cultural values in the Ho Chi Minh heritage treasure has achieved many achievements, but there are still certain limitations. To achieve research goals and hypotheses, the author has used scientific research methods such as analysis and synthesis, deduction and induction, abstraction and generalization, logic and history, and comparison to come to the findings and recommendations on the education of the traditional cultural values of the Ho Chi Minh heritage treasures in Vietnam today. The results of the study show that the education of traditional cultural values in the Ho Chi Minh heritage in Vietnam has contributed to the socio-economic promotion, political stability, and improvement of the material and spiritual life of the people. The treasure of Ho Chi Minh's heritage consists of 4 traditional values (components): traditional patriotic spirit, the tradition of compassion and solidarity; spirit of tolerance, and language and voice of the nation.
\end{abstract}

Keywords: Cultural Value Education, Tradition, Ho Chi Minh Heritage

\section{Introduction}

Educating traditional cultural values in the treasure of Ho Chi Minh's heritage in Vietnam has an important role in the development of the country. Currently, culture, like other fields, is a part of the Vietnamese revolution. The Communist Party of Vietnam takes Marxism-Leninism and Ho Chi Minh's thought as the foundation, lighting the way for the path of building and developing a new Vietnamese culture. During the revolutionary period, the Party always identified culture as the front that the Party must lead. Under the leadership of the Communist Party of Vietnam, there has been many important achievements in culture.

President Ho Chi Minh has left our Party and people a great and profound ideological legacy which is the combination of national and human cultural values and the creative application of Marxism-Leninism to the specific conditions of Vietnam to liberate the nation, classes, and people. His thought has become the foundation and guideline for the actions of the Party and the Vietnamese revolution. It is also an invaluable asset of the Party and our people.
Therefore, studying Ho Chi Minh's thoughts is an important and long-term task of many generations of Vietnamese people and needs to be further promoted in the period of industrialization and modernization of the country.

Of his whole system of thought, culture is a field where Ho Chi Minh has made great contributions. UNESCO has recognized President Ho Chi Minh as "Vietnam's hero of national liberation and outstanding cultural celebrity". $\mathrm{He}$ fought and sacrificed his whole life for the cause of Vietnamese national liberation and the progress and civilization of mankind. As an outstanding cultural celebrity, Ho Chi Minh represented the essence of national culture. His ideas are the mixture of the thousands-year-old tradition of the Vietnamese people and the embodiment of the nations in affirming their national identity. He has also connected the traditional values of the nation with the cultural quintessence of humanity in many different aspects. His ideological values are not only valuable in the past but also have great value in the present and future. In the whole value of Ho Chi Minh's ideology and culture, there is an issue that we need to pay special attention to, that is, preserving and promoting the 
national cultural values in the treasure of Ho Chi Minh's heritage in Vietnam today.

The cultural ideological heritage of Ho Chi Minh, with preserving and promoting the national cultural tradition in building a new culture today, has a particularly important meaning in the development strategy of the country. It is not only a goal to reach the noble values of life, but it also plays the role of a great foundation and strength in economic and social development. National culture is the vitality of economic and social development and promotes all human activities. Today, the development of the country is not only economic development, science, and technology, but also requires the development of culture - the spiritual life of the society. Culture is identified as the driving force of socioeconomic development. Our Party has deeply realized that preserving the national cultural tradition is the need of the nation, the need of the new culture. The cultural tradition of Vietnam has great significance for the nation, it is an invaluable asset of the nation forged through thousands of years of national history. Therefore, we can affirm that the preservation and promotion of national cultural traditions have significance and play an important role in the cause of building a new Vietnamese culture at present.

The study and clarification of several theoretical-practical aspects, as well as the current situation and solutions for the education of traditional cultural values of the nation in the treasure of Ho Chi Minh's heritage in the process of building Vietnamese culture and socialist modernization, actively contributing to the country's construction in the current period is necessary and is a topical and scientific study.

\section{Literature Review}

Globalization is an inevitable and objective law in world economic exchange and integration. Accordingly, there are also other global forms, including culture. The culture of many peoples is at risk of being assimilated before the cultural invasion of countries with strong economies. The protection of national culture, raising the position of national culture in international exchange and cooperation is one of the prerequisites.

Talking about inheritance in culture is, first of all, talking about cultural traditions. Because the focus in preserving culture is that every new thing born is based on the old, the old creates the premise for the new to be born and develop. There would be no present and future, without tradition, the nation's history would be interrupted. Tradition is the bridge between the past, present, and future. The past always leaves more or less traces in the endless flow of time. The issue of preserving, inheriting, and promoting culture was of particular interest to Lenin. He said that, if we do not preserve, inherit and absorb the heritage, cultural achievements, science, and technology of mankind, and especially capitalism, "we have no other materials." [1]. The United Nations initiated: "World Decade of Cultural Development" (1987 - 1997) to protect, preserve, and enriching national cultural identities, promoting all possibilities of innovation. individuals and collectives in promoting national cultural identity in construction and development. UNESCO mentioned three priority areas: protection and preservation of cultural heritage; creative transformation of culture; cultural preservation and renewal.

Humanity is entering the century of modern civilization. A century of changes in all aspects at breakneck speed. People worry that, how can that civilized, modern society develop without separating from tradition. From the beginning of the twentieth century, John Jorés, a leader of the French socialist movement said: "Being faithful to tradition is not about going back to faded times as to gazing at a long line of shadows Ghost, but on the contrary, is to put all his strength forward to the future, just as the river must go to the sea for the river to be faithful to its source." [2].

President Ho Chi Minh once emphasized the issue of preserving, inheriting, and promoting national traditional values to build a new life in particular and to build a culture in general: "What is old and ugly must give up; something old but not bad but annoying must be modified to make it reasonable; what is good must be further developed; something new and good must be done. How to make the life of our people, materially more complete, that is the purpose of the new life [3].

The Fifth Conference of the Central Committee of the Party, term VIII, commented: "The cult of foreign countries, disregard for national cultural values, pursuit of a pragmatic lifestyle, and selfishness are harming pure culture customs of the nation. In many cases, because of money and fame, trampled on family affection, teacher-student relations, comrades-in-arms. Smuggling and corruption flourished. Drugs, prostitution and other social evils are on the rise" [4]

At the 11th National Congress of the Party, the Party continued to comment: "The cultural environment is violated, strained, unhealthy, contrary to fine customs and traditions, social evils, crime, and invasion. Importation of harmful products and services that degrade morals, especially among young people, is very worrying" [2]

At the 7 th Congress, our Party advocated building and developing the cultural cause of Vietnam, preserving and promoting the fine traditional cultural values of the ethnic groups, absorbing cultural quintessence. mankind. At the 10th conference, the IX Central Committee of the Party, our Party affirmed: "In the new era, selectively inheriting and preserving traditional values is inevitable; at the same time must focus on building new values and new achievements to meet the needs of the national renewal process. Preserving, inheriting, and promoting culture is always closely associated with the process of opening up, integrating, and receiving the values of the contemporary world, to enrich national values, and improve the development level of the country. Vietnamese culture to new heights" [5]

Currently, there are many research works on the viewpoints and education of traditional cultural values of the nation in the treasure of Ho Chi Minh's heritage. In the study "Understanding Ho Chi Minh's thought on youth mobilization", Van Tung mentioned the contents of Ho Chi 
Minh's thought in youth mobilization and partly mentioned the values of traditional culture in the youth movement education for Youth [6]. Researching on Vietnamese youth with patriotism in national history, Duong Tu Dam shows that patriotism is a cultural and traditional value of the Vietnamese nation, which was elevated to a level by Ho Chi Minh. new heights, patriotism associated with determination to achieve independence and freedom for the nation [7].

Learning about Value Orientation for youth among students today, the Youth Committee of Schools in Vietnam indicates that in addition to patriotism, the Vietnamese nation and people also have a tradition of kindness and affirmation. This tradition is not only limited to the country but it has reached the international arena [8].

Researching on Revolutionary Ideals Education for Youth in the Doi Moi period, Nguyen Hai Yen also mentioned the tradition of solidarity and patriotism in the archives of Ho Chi Minh Thought, but also deeply mentioned the spiritual tradition of Ho Chi Minh. The spirit of tolerance in many areas of life in Ho Chi Minh Thought is crystallized from the tradition of the nation [9]. Resolution on Strengthening education on morality and lifestyle, fostering revolutionary ideals for young people in the period of 2013-2017, the Central Committee of the Youth Union is behind on preserving the language and voice of the nation one by one. completely is a very necessary requirement in the process of international integration. Because the Vietnamese language has become the weapon of the Vietnamese nation, making the Vietnamese nation the independent nation it is today [10]. In his research on Learning and following Ho Chi Minh's moral example on education and training young people in the new situation, Nguyen The Thang also said that studying and following Ho Chi Minh's moral example is learning practice on values crystallized in human thought such as patriotism, love of labor, love of people in the implementation of the revolution of industrialization and modernization in Vietnam today [11].

Although the above research results have not created a unified and comprehensive whole, they have provided many theoretical aspects and suggested many important contents for the following people to continue to improve, to fill the void on this topic. Stemming from that fact, the author studies the education of traditional cultural values in the treasure of Ho Chi Minh's heritage in Vietnam today. Our approach is based on the perspective of Political Science, which considers all the components constituting the educational contents of traditional cultural values of the nation in the treasure of Ho Chi Minh's heritage.

In this study, the author believes that: Educating the traditional cultural values of the nation in the treasure of Ho Chi Minh's heritage in Vietnam is an educational activity about the values Vietnamese culture has molded into the soul, mettle and bravery about Ho Chi Minh people make the nation's history shine. The treasure of Ho Chi Minh's heritage is composed of 4 traditional values (components): i) traditional patriotic spirit; ii) the tradition of compassion and solidarity; iii the) spirit of tolerance; iv) Language and voice of the nation.

\section{Results and Discussions}

Vietnamese culture has made great contributions to the nation's resilient struggle, building and defending the country, as a result of educating generations of traditional cultural values in Vietnam. During the Ho Chi Minh era, Vietnamese culture continued to be promoted and developed, making a decisive contribution to the great victories of our people in the cause of national liberation and the construction of a socialist festival. In the past years, the education of traditional cultural values in the Ho Chi Minh heritage in Vietnam has contributed to the socio-economic promotion, political stability, and improvement of the material and spiritual life of the people specifically on the sides as follows:

\subsection{Traditional Spirit of Patriotism}

This spirit, raised by Ho Chi Minh to patriotism, is associated with the determination to gain independence and freedom for the nation. With that spirit, the Vietnamese people went to victory in the August Revolution, the war against the French, the US, and Vietnam opened a new era, the whole country went up to socialism.

Over the years, Vietnamese patriotism has continued to be promoted in new historical conditions. Today's patriotism is to uphold national independence, protect the socialist regime, and be determined to move up to socialism. Patriotism now must be expressed by the determination to bring Vietnam out of the status of a poor country, must be determined to strive to realize the goal of building a country of rich people, strong country, democracy, and justice. civilized. Patriotism manifests itself in all levels, all branches, and all areas of life.

In the field of economy, most sectors and fields of the economy have made good progress, with the average economic growth rate of 5 years reaching 7\% [12]. People's living standards are improved and enhanced. The economic structure continues to be transformed towards industrialization and modernization. Vietnam from a country that must import food, in recent years has become a rice exporter ranked second in the world.

In the field of politics, the organizational structure of the state apparatus has been consolidated, with many innovations and improved operational quality. The Party building and rectification work have been strengthened, the Party's leadership method continues to be renewed while ensuring the Party's leadership while promoting the initiative and creativity of organizations in the political system. treat. The expansion and promotion of democracy within the Party are focused and appreciated.

In the field of culture - society, cultural and artistic activities have been expanded, gradually meeting the increasing demand for cultural enjoyment of the people. The issue of job creation, hunger eradication, and poverty reduction achieved positive results. In 5 years, it has created jobs for over 8 million workers, the unemployment rate in urban areas decreased to less than $4.5 \%$, the rate of poor households decreased to $9.5 \%$. The prevention and overcoming of environmental pollution degradation are 
concerned. Education reform has achieved some initial results. State budget expenditure on education and training has reached over $20 \%$ of total budget expenditure [13].

In terms of security, defense, and foreign affairs, the potential for national defense and security has been enhanced. The work of education and fostering knowledge of national defense and security has been widely deployed. Foreign relations have been expanded and deepened, contributing to creating a new position and force for the country. Our country has joined the World Trade Organization (WTO), signed bilateral and multilateral free trade agreements with many partners; expand and strengthen cooperation, attract foreign investment, etc.

The achievements in the fields of culture, economy, politics, security, and defense in recent years are due to the promotion of patriotism of all classes and classes in Vietnam. All those achievements have made great contributions to the development of the country and contributed to the successful construction of socialism.

\subsection{Tradition of Kindness and Solidarity}

In recent years, the market economy has shown its dynamism and superiority compared to the economy operating under the centralized bureaucratic and subsidized mechanism. The good thing is, the spirit of kindness continues to be preserved, inherited, promoted, and raised to a new height by our people in building their lifestyle. In society, everyone knows how to love, share, and tolerate each other. Many people have saved money, donated to build schools in difficult areas, build houses of gratitude, give scholarships, etc. All of them enthusiastically contributed their efforts to deeply meaningful movements such as relief for people affected by natural disasters, building houses of gratitude - houses of compassion, hunger eradication and poverty alleviation, fundraising for scholarships, implementation of civil works, etc., creating a spillover into a movement throughout the country.

The compassion of our people today is not only limited to the country, but it has extended beyond borders, reaching countries in the region and internationally. We have sent shipments, money to help friends in difficulty, for example, we supported the people of Japan after the earthquake and tsunami disaster.

The Party and State have promulgated resolutions, guidelines, policies, and laws to arouse and promote the creativity of all classes of people, and to strengthen the great unity of the whole nation. Promoting the role of dignitaries, intellectuals, typical people of ethnic minorities, religious dignitaries, and overseas Vietnamese in campaigning for the building of the great national unity bloc. In recent years, the Vietnam Fatherland Front has well organized the Great National Unity Day (November 18 - the day of the establishment of the Unified National Front in Vietnam) in almost all residential areas throughout the country. The festival has aroused and promoted the tradition of solidarity and patriotism, a vivid expression of the spirit of great national unity in the new situation.

\subsection{Spirit of Tolerance}

Ho Chi Minh mentioned the spirit of tolerance in many areas of life, but his spirit of tolerance shows most profoundly towards religion and those who have done wrong things. Over the years, we have inherited his ideas about tolerance in various fields, but here we are only talking about religious tolerance and to those who have "gone astray".

In Vietnam, the spirit of tolerance in the field of religion is not only reflected in the respect for spiritual needs but there is an awareness that all major religions have one thing in common: teaching people to do good, avoiding evil, directing people to the common origin of mankind, towards Truthfulness - Compassion - Beauty.

Belief and religion are spiritual needs of a part of the people and are existing with the nation in the process of building socialism in Vietnam. Over the years, our Party and State have consistently implemented the policy of respecting and guaranteeing freedom to believe, to follow, or not to follow any religion. We have done a good job of mobilizing the masses, taking the goal of a rich people, a strong country, a just, democratic, and civilized society as a common point to unite and attach religions to the cause of construction and development. protect the country.

In the spirit, the tradition of his father taught: "hit those who run away, no one beats those who run back". No matter how badly you make a mistake, you can fix it, and when you realize your mistake, it's much more valuable.

For those who have "gone astray", the Party and State have adopted appropriate policies to arouse their spirit and belief. As in the "Testament", President Ho Chi Minh also said: "For victims of the old social system, such as theft, prostitutes, gambling, smuggling, etc., the State must use both education and education., must use the law to reform them, help them become honest workers" [14]. On New Year's Eve, the President signed a decree on special amnesty and amnesty for well-reformed prisoners in extremely difficult circumstances. It is a manifestation of our State's leniency towards those who have gone astray, always creating conditions for them to be good. That is also the moral tradition of the nation.

\subsection{Language and Voice of the Nation}

In the current period, when society is developing more and more, it requires us to integrate into the world in all aspects. In terms of cross-cultural exchange, it can be said that if one language is lost, the world loses a part of human cultural diversity. Therefore, preserving the language and voice of the nation in its entirety is a very difficult requirement. And the protection of language is the protection of national cultural identity. But over the years, the language of the nation has been promoted and used effectively. Although our language still has to be borrowed from foreign countries, it still retains its own and unique characteristics of the nation. There are many literary works born that still retain clear and simple language.

The Vietnamese language has become the weapon of the Vietnamese nation, bringing the nation out of all shackles of 
slavery to become an independent nation as it is today. Not only that, but it also makes Vietnamese identity and is the pride of the nation. In all aspects of the life of a nation, a country, language is most closely associated with culture. Language is one of the important factors contributing to the foundation of values, identity, and quintessence of the national culture.

Vietnamese is a place to record, a place to reflect knowledge, experiences, thoughts, concepts, etc. along with the process of formation and development of Vietnamese culture, the Vietnamese language is also formed and developed. Today, it has become a beautiful, rich, and unique language, it is a very effective tool in building and developing an advanced Vietnamese culture imbued with national identity.

Over the years, preserving and promoting the national cultural tradition in the cause of building a new Vietnamese culture today according to Ho Chi Minh's thought has contributed to the development of the country. With the efforts of the entire Party and people, we have achieved many achievements in this field. However, with the requirements of the cause of national construction in general, building a new culture in particular, the preservation and promotion of national cultural traditions according to Ho Chi Minh's thought, we still have many challenges. certain restrictions.

\section{Conclusion}

The cultural ideological heritage of Ho Chi Minh is the foundation for us to understand more about the issue of preserving and promoting national cultural traditions in our country today. The process of preserving and promoting national cultural traditions to build a new culture in Vietnam today must derive from the goals, tasks, and contents of building a new culture that the Party has set out, it is necessary to select positive values in the cultural traditions of the nation. In this study, the author came to the following conclusions:

The author has summarized the authors' research as well as the ongoing theoretical and practical perspectives on the education of traditional cultural values of the nation in the treasure of Ho Chi Minh's heritage in Vietnam. In particular, the author mentioned and clarified that this concept is composed of 4 basic components.

The research has pointed out that 4 traditional cultural values in Ho Chi Minh heritage are the foundation for creating the soul, mettle, and bravery of the Vietnamese people today. The traditional patriotic spirit is an outstanding traditional cultural value of the Vietnamese nation, raised to a new height by Ho Chi Minh, patriotism associated with the determination to win independence and freedom for the nation. That patriotism helped us to win in the August Revolution, followed by victory on April 30, 1975, Vietnam opened a new era, the whole country moved to socialism. The tradition of compassion and solidarity of our nation today is not only limited to the national scope, but it has extended beyond borders, reaching countries in the region and internationally. The spirit of tolerance in many areas of life, but the spirit of tolerance in Him is most profoundly expressed towards religion and those who have "gone astray". The language and voice of the nation have become the weapons of the Vietnamese nation, bringing the nation out of all "shackles" of slavery to become an independent nation as it is today.

\section{References}

[1] Van Lang, Quynh $\mathrm{Cu}$ \&Nguyen Anh (1989). Famous Vietnamese people Hanoi: Youth Publishing House, Volume 2, p. 11.

[2] Communist Party of Vietnam (2011): Document of the 11th National Party Congress, Hanoi: National political Publishing House, p. 169.

[3] Ho Chi Minh (1995): Anthology of Literature, Hanoi: Literature Publishing House, Volume 2, p. 152.

[4] Communist Party of Vietnam (1998): Fifth Conference, 8th Party Central Committee, Hanoi: National political Publishing House, p. 46.

[5] Vo Van Thang (2005): Inheriting and promoting the virtue of diligence in building the lifestyle of Vietnamese people today, Journal of Social Sciences, No. 79, p. 57.

[6] Van Tung (2002). Understanding Ho Chi Minh's thought on youth mobilization, Hanoi: Youth Publishing House.

[7] Duong Tu Dam (2008). Vietnamese youth with patriotism in national history, Hanoi: Youth Publishing House.

[8] School Youth Committee, (2007), Value orientation for youth among students today. Hanoi: Youth Publishing House.

[9] Nguyen Hai Yen (2010), Revolutionary ideal education for young people in the renovation period, Journal of theoretical education, Academy of Politics Region I.

[10] The Executive Committee of the Central Youth Union (2013), Strengthening education on ethics and lifestyle, fostering revolutionary ideals for young people in the period 2013-2017.

[11] Nguyen The Thang (2014), Studying and following Ho Chi Minh's moral example on education and youth training in the new situation, Hanoi: Youth Publishing House.

[12] Communist Party of Vietnam: Document of the 11th National Party Congress, Hanoi: National political Publishing House Hanoi, p. 151.

[13] Communist Party of Vietnam: Document of the 11th National Party Congress, pp. 153-154.

[14] Ho Chi Minh: Complete works, Vol. 12, p. 504. 